\title{
The Impact Of Macroeconomic Variables On Stock Market - Empirical Evidence On Karachi Stock Exchange By Using Ardl Model
}

\author{
Adnan Javed ${ }^{1}$, Muhammad Rafiq ${ }^{2}$, Sarfaraz Khan ${ }^{3}$, Muhammad Mohsin Khan ${ }^{4}$
}

\begin{abstract}
This research work provides a broader area to examine the impact of macroeconomic variables on Karachi Stock Exchange. KSE-100 index data is the dependent variable while macroeconomic variables are independent variable. CPI, foreign exchange rate, foreign portfolio liabilities (equities), oil prices and t-bill rates are selected as macroeconomic variables. Data is collected quarterly from the period of 1992 to 2009. A powerful ARDL model is used in this research work. Result of the $A R D L$ model shows that CPI, exchange rate, and t-bill rates got negative relationship with KSE-100 index. Foreign portfolio liabilities (equities) and oil prices showed positive relationship with KSE-100 index.
\end{abstract}

Keywords: Stock exchange, ARDL model, Foreign Portfolio, Liabilities.

Field: Finance and economics.

\section{Introduction}

A place where securities or company shares are listed as well as bought and sold is called stock market. Trading is done either through stock exchange or over the counter market. Equity market is the other name of stock market. Investors and companies mutually benefitted each other, by getting access to the capital and a slice ownership in the company. The role of Stock exchange is very important for economic development and growth. Business activities in the country are boosted by stock exchange through selling shares and raising capital for the company. Savings of the people, if are allocated to invest in stock exchange, instead of keeping it idle somewhere, it will promote productivity and confidence in the economy. Not only large investors can participate and take ownership in the company but small investors also get a change and participate by buying shares up to their buying power. In this way, it prepares

1 Assistant Professor at Institute of Management Sciences Peshawar, Pakistan. Email:adnan.javed@imsciences.edu.pk

2 Assistant Professor, Institute of Management Sciences Peshawar, Pakistan.

3 Institute of Management Sciences Peshawar, Pakistan.

4 Joint Director, Institute of Management Sciences Peshawar, Pakistan. 
and organizes the domestic resources and passes them into some productive investment. An efficient and stable stock market prices is directly related with economic stability. Any recession, depression or prosperity in the economy can change the stock market price momentum.

Ross (1976) proposed the APT to calculate the assets returns and their dependency on various factors. Based upon this approach, Chen, Roll and Ross (1986) analyzed the relationship of security returns and few macroeconomic variables. They examined that few variables like inflation, GNP and default premium of corporate bonds were highly significant in changing the security returns. After this research, many researchers work on stock market fluctuations in relationship with economic variables. Some stock market that they observed were from developed countries and some were from developing countries. Chen et al (1986), Thornton (1993), Kaneeko and lee (1995), and Darrat and dickens (1999) worked for developed countries. In their study, their key findings were the relationship between industrial production index, inflation, money supply and stock market return. Mukherjee and Yu (1997), Maysami and Koh (2000), kwon and shin (1999) worked for developing economies. They found that M2 money supply, foreign exchange reserves and exchange rate, oil price were highly significant in explaining the changes in stock prices.

Nishat and Shaheen (2004) used the VECM model to find the relationship between macroeconomic variables and stock market prices. They found that IPI is positively and CPI is negatively affecting the stock market prices. Same relationship was also find out by Sulaiman, Hussain, Jalil and Ali (2009) by using ARIMA model and found that M2 money supply foreign exchange rate, and IPI were positively affecting the stock prices. Their researches were not satisfactory because the model that they used were not powerful and can be run even with the low power of order. Secondly, they collect data before the liberalization of Karachi stock exchange in 1991.

Akmal (2007) used the power ARDL model to investigate inflation and stock market relationship. His research was quite satisfactory but due to less economic variables, his research was not fully explaining the change in stock prices. Finally the most impressive work was done by Hassan and Nasir (2008) by applying ARDL model. He used monthly data for 10 years. In his research, he used such variables which were inter-related to each other. Like money supply, interest rate and inflation which were highly correlated with each other. If one of these variables rises, the second also rises but falling in other variables occurs. So the results were being disturbed by such inter-relationship between the independent variables. 
The research chooses ARDL model in this research work because it has the ability to be run even not regarding the size and integration order of the sample data. This model allows us to explore the correct dynamic structure and it can accommodate a lot of variables as compare to other variables as compared to VAR model. I collect Quarterly data of five major economic variables which are CPI, t-bill rate, oil prices, exchange rate and foreign portfolio investment liabilities (equities) from the period of 1992 to 2009. On dependent side, I kept KSE-100 index data. This part will cover only the research methodological section. Some of the questions which this research work tries to answer are that how much the stock market index can be affected by the macroeconomic variables? With the different unit root order, how can the relationship between the macroeconomic variables are affected, whether positively or negatively?

Developing countries like Pakistan has always faced with inflationary and financial problems. But as Pakistan economy and Karachi Stock Exchange were moving towards the stability as we move from 1992 data and onward. So the research work would not be any much different from the developed countries researches.

\section{Literature review}

Ibrahim and Aziz (1998) used VAR model in their research to find out long run and short run relationship among variables. This model also helps them to figure out variance disintegration and encourage impulse response functions to map out the granger causal links in all the variables.

Menik (2002) used the very simple multi-regression method to find the effect of macroeconomic variables on stock price in Colombian stock exchange. He thinks that capital markets are very helpful for economic development. Sri Lankan government was giving different incentives for both foreign and local investors to invest in stock exchange. So Menik was much excited for to find whether the macroeconomic policy has some link in booming the stock exchange and economy.

Nishat and Shaheen (2004) were also focusing on to find the long run relationship between the stock prices and macroeconomic variables. For the stock prices, they used the KSE index. These variables were used as independent variables while KSE index were used as dependent variable. In their research, VECM (vector error correction model) were used. Gay (2008) has analyzed the macroeconomic variables on the equity market prices for four emerging economic country of the world. These economic countries were Brazil, 
Russia, India and China. During this time and now, these countries were progressing in a very high rate. Their capital markets were on the peak and moving upward, still now. So he designed this research as how these emerging countries react with macroeconomic variables. VAR model was used in this research in order to find out the long run and short run relationships among the selected variables. This model also helps them to figure out variance disintegration and encourage impulse response functions to map out the granger causal links in all the variables.

Long term relationship has been finding out like other researchers by, Hassan and Nasir (2008). They tried to find out the main variables that what is causing much fluctuation and volatility in the capital market. The main characteristic which differentiates their work was using the ARDL approach. According to them, this approach is helpful in allowing the inferences on long run estimates that were not possible in other alternative co-integrative procedures. This approach doesn't take care of stationary or non stationary property of the data. In comparison to VAR model, it can accommodate a greater number of variables. Mohammad, Hussain, Jalil, and Ali (2009) conducted a research to find the correlation between the macroeconomic variables and share prices in KSE. They conduct this research to find the correlation among their variables which they had selected. Like other researches, this research has also shown a significant effect of macroeconomic variables on stock market prices. Buyuksalvarci (2010) similarly conducted the research on as to how the macroeconomic variables put pressure on stock market return. He also tries to analyze the effect of these variables on capital market efficiency. He conducted this research on Istanbul stock exchange. His whole research was under the framework of arbitrage pricing theory (APT), which was presented by Ross (1976). Ibrahim and Aziz (1998) on their research work on macroeconomic variables and Malaysian stock market, took the variables which they selected were industrial production index, price level, M2 type of money supply and exchange rate. All the data were collected on the monthly basis from the period of 1977 to 1998. It becomes 22 years of data observations. On the dependent side KLC-100 index data was placed.

Menik (2002) took the monthly data from the period of 1991 to 2002, for his research work on Colombian stock exchange. It becomes the 136 monthly data. 242 stocks were listed on the Columbian stock exchange during this time but he took 34 main listed companies which have frequent trading behavior in comparison to other companies. Multivariate regression is used in his research. The main variables which were used as macroeconomic are; money supply, exchange rate, inflation rate, t-bill rate for the companies at a time, while 
other four variables were the same as above but the rest four were used as $t-1$ data for the company he choose. All the dependent and independent variables were transformed to natural $\log$. And then the regression was run.

Nishat and Shaheen (2004) similarly did work on Karachi stock exchange. From the macroeconomic variables, they used the industrial production index, cost price index, M1 type of money, inter-bank interest rate. These variables were used as independent variables while KSE index were used as dependent variable. In their research, VECM (vector error correction model) were used. The data were collected quarterly from the period of 1973-2004.

Gay (2008) has analyzed the macroeconomic variables on the equity market prices for four emerging economic country of the world. Two well known macroeconomic variables such as exchange rate and oil prices were selected as independent variables while stock market index prices were selected as dependent variable. Almost 90 observations were taken for each variable and for each country.

Hassan and Nasir (2008) tried to find out the main variables that what is causing much fluctuation and volatility in the capital market. Macroeconomic variables and Pakistan capital market has been regressed. The main variables which they include in their research were the industrial production index, oil prices, exchange rate, inflation, T-bill rate and foreign portfolio investment. Data were being collected from the period of June 1998 to June 2008. All the data were collected on monthly basis.

Mohammad, Hussain, Jalil, and Ali (2009) conducted a research to find the correlation between the macroeconomic variables and share prices in KSE. They took the share prices as a dependent variables and macroeconomic variables as independent variables. Monthly and time series data were being used in their research from the period 1986 to 2008.

Buyuksalvarci (2010) similarly conducted the research to show that how the macroeconomic variables effect the capital market efficiency. He conducted this research on Istanbul stock exchange. He selected macroeconomic variables like CPI, interest rate, gold prices, industrial production index, international crude oil prices, foreign exchange rate and broad money supply. Monthly wise data were being taken from the period of January 2003 to the march 2010. ISE-100 index return was taken as dependent variable while macroeconomic variables were used as independent variables. 


\section{Theoretical Framework}

\subsection{Macroeconomic variables}

\subsubsection{Oil prices}

Oil is an important element in today's production in almost any sector of economy, whether it is directly or indirectly. So any change in oil prices may result in effecting the cost of production and also the profit for a company/ corporations. Many researchers have used different models to test whether the oil prices changes the stock prices or not.

Noreen, Roohi and Mustafa (2005) studied that there was no any impact of oil prices on stock market returns in Pakistan. He explained with the reason that gas is more used than oil in Pakistan. Fayoumi (2008) concluded from his results that change in oil price will not bring any much change in stock market returns. This was the case for oil importing countries. Hassan and Nasir (2008) applied ARDL model approach on oil prices and stock market returns. He found a slight or negligible relationship between the two variables in the long run. Similarly, Gay (2008) applied ARIMA model on emerging countries and found no any country stock market returns to be volatile with the variation in oil prices. Ramos and Viega (2009) examined the 43 international stock markets. He noticed that developed countries have a negative relationship of oil prices with stock market returns due to variation in oil prices. However, according to him, emerging countries stock markets do not respond to any change in oil prices. Samuel (2010) examined the relationship of stock prices and oil prices on Oil producing and consuming countries. He finds the co-integration relationship between the two variables. Amine and Bellalah in the same year researched on oil exporting countries and found no any effect of change in oil prices on stock market returns.

\subsubsection{Exchange rate}

Foreign exchange rate means that how much one currency is worthy in against to another country currency. Two well known types of exchange rates are quoted in the exchange market that is spot exchange rate and forward exchange rate. Spot exchange rate is the price quoted at current rate. While forward exchange rate is the rate specified at some future date. Exchange rate changes either due to more demand or supply of a currency or through speculative demand. Speculative demand arises when an investor tries to buy a currency that has higher interest rate either now or in future. 
Within an economy, two main types of firms operate which are multinational and domestic firms. Multinational firms profits varies and dependent on exchange rates. So, if their profits changed due to exchange rate, then the firms' value can change the stock prices due to low economy output. Similarly, domestic firms also depended upon the exchange rate because they do import and export of goods in foreign currency. Pakistan is the least exporter and more importers of goods from many countries. So any appreciation and depreciation of its currency can have significant effect on production cost and domestic market. The economists have proposed their own views regarding this aspect through their researches.

Ishfaq, Rehman and Raoof (2010) studied that increase in exchange rate lower the production cost and increases the returns. While if own country currency depreciates, then the foreign investors who have invested in our market will have a lower stock market returns. Aggarwal (1981) stated that exported firms will makes much profit in devaluation of its own currency. Their income level rises as well as stock prices. Adjasi, Harvey and Agyapong (2008) studied the exchange rate volatility and stock market volatility. He showed a negative relationship between the exchange rate volatility and stock market volatility. Further he explained that when a local currency depreciates, then the stock market will give a higher return in long run. But the case will be opposite in short run.

\subsubsection{T-bill rate}

It is called Treasury bill which is issued by a government to reduce the money supply. It is a kind of debt obligation of a government, which the government has to pay back before or at the time of maturity. Before maturity, $t$ bills are sold at discount from face value and no interest will be paid. Their return are called risk free rate of return because there would be no risk involving in paying back by the government. Trevino and Yates (2007) stated that Investment in t-bills is a bad idea during higher inflation in long run because their return will be lower in both nominal as well as in real term. But in short run, t-bills would give a good return than stock and bonds. Amadi (2007) found no correlation between stock return and risk free rate of return. It means that risk free rate has no effect on stock market return. Nousheen, Urooj and Durrani (2008) concluded from his research that interest rates have a strong power to control money supply and stock prices. When an interest rate rises, then people try to save their money bank to earn extra profit. This will reduce the firm's profits and ultimately will make the stock prices down. So interest rate has a negative relationship with stock prices. Further he stated that we 
can estimate the stock return by knowing the interest rate but we can't be able to predict the volatility in stock market. Buyuksalvarci (2010) found negative relationship of t-bills rate with stock market return. Hassan and Nasir (2008) clearly showed that along with exchange rate and money supply, interest rates are best in predicting the direction of equity prices in capital market. Menik (2002) finds from his research results that whenever there was any increase in the interest rate, then the investor tries to switch out of the stocks which directly affect stock prices to fall. T-bill rate are used as a proxy of interest rates. From the above literature I concluded that t-bills have a negative relationship with stock market return.

\subsubsection{CPI}

CPI is the abbreviation of consumer price index. It shows that how much a consumer can buy a basket of goods, given his income level. CPI is the general term used for inflation rate of an economy. Inflation rate is the general increase in overall price level within economy, whether it is food prices or non-food prices level. From an investment point of view, investor should look at the current inflation rate while investing in securities. Pakistan as a developing country, has suffered a lot from inflation disease. On February 2011, inflation has been recorded as $16 \%$. Increase in money supply, rise in food oil prices has been considered as the real cause of inflation.

Yuan and Chan (2010), Nishat and Rozina (2004), Chen, Roll and Ross (1986), Mukherjee and Naka (1995), from their empirical results concluded that stock market returns and inflation rate has a negative relationship with each other. Based on their relationship researches, only low and negligible effect relationship has been found out. So I hypothesized her that the stock market return and inflation rate will have low and negligible relationship.

\subsubsection{Foreign portfolio investment liabilities (equities)}

FPI is the buying of foreign stock market shares, bonds etc. normally, their buying is for a short term speculative purposes. Foreign portfolio investments are made in foreign currency. So, automatically the receiver country gets foreign currency in turn. Pakistan received an extra $27 \%$ of foreign investment in February 2011 as compared to previous fiscal year. Around \$242 million of FPI has been recorded in the current fiscal year. FPI has been recorded in the current fiscal year. FPI is very helpful for an economy like Pakistan, because it improves the liquidity position and foreign reserves of an economy. Business firms issue new shares in the capital market and in turn, they get capital for their business operation. 
Poshakwale and Thapa (2007) showed that Indians stock market have a positive relationship with inflow of FPI. This lays a positive effect on widening of equity market activities. In this way, FPI influence the movement in stock prices. Hassan and Nasir (2008) proves by an empirical analysis that FPI is a significant factor in short run for stock market prices while it is non-effective in long run. Overall discussion shows that FPI has a positive impact on stock return.

\section{Methodology}

Ibrahim and Aziz (1998) used the VAR model in their research. This model helps them to figure out variance disintegration and encourage impulse response functions to map out the granger causal links in all the variables. They also used the rolling regression with the fixed window size of 13 years to further stimulate the impulse response function. Menik (2002) used the very simple multi-regression method to find the effect of macroeconomic variables on stock price in Colombian stock exchange. Multivariate regression is used in his research. All the dependent and independent variables were transformed to natural $\log$. And then the regression was run.

Nishat and Shaheen (2004) find the long run relationship between the stock prices and macroeconomic variables. In their research, VECM (vector error correction model) were used. In their research there was one thing special that all other variables except the interest rate were transformed to natural log. VECM model was used to testify the co-integration in the data, which were being collected. For the model to be used, ADF test was made to find whether all the data were in proper order in the series. The data were assumed to be in order of one for the integration process. In ADF test, two specifications which were constant and trend, and a constant only, were made to estimate. To find whether any independent variables have caused more or less the dependent variable, granger causality test was used.

Gay (2008) used the ARIMA model (autoregressive integrated moving average) in his research to find the macroeconomic variables relation with equity prices on four emerging economic country of the world like Brazil, Russia, India, and china. In this model all the dependent and independent variables were converted into $\log$ form and moving average were made for the variables in the respective manner of the months such as for 1 month, 3 months, 6 months and for the 12 months. As the model requirement, discrete data set were chosen to verify equally spaced values by having no missing values. For the stationarity of the data, the famous ADF test was conducted. First order differentiating method was used in this test, which removes the stochastic trend showing a constant mean. 
Long term relationship has been finding out like other researchers by, Hassan and Nasir (2008). The main characteristic which differentiates their work was using the ARDL approach. Further, they did the tests like LM, Ramsey reset test, ADF and Philip Parren test on the data. Mohammad, Hussain, Jalil, and Ali (2009) in his research on, to find the correlation between the macroeconomic variables and share prices in KSE, used auto regressive integrated moving average (ARIMA) model. They observed that during this time period, most of the data were not stationary. Non-stationary means that they were not constant and changing randomly. For such type of non stationary data and analysis, ADF (augmented dickey fuller) test were made. Buyuksalvarci (2010) similarly conducted the research on Istanbul stock exchange. His whole research was under the framework of arbitrage pricing theory (APT), which was presented by Ross (1976). Multi linear regression method was used to solve the problems and find the estimates variables. As he used OLS method to compute the estimates of the model variables, but before finding the results, he applied the ADF and Philips perron unit root tests. The tests were performed to find the stationary property in the data that he took for the research.

Ibrahim and Aziz (1998) gathered the data and then the data were empirically tested and analyzed that there were existence of long run relationship between the dependent and independent variables. Significant short run relationships were also noticed among the macroeconomic variables and stock prices. Exchange rate was negatively related with the stock prices. Money supply which have a positive liquidity effects, have a negative relation with the stock prices. The same effect of money supply was also noticed in case of long run relationship with macroeconomic variables by using rolling regression method.

Menik (2002) used the very simple multi-regression method in his research. In his research findings, he noticed that 27 companies out of selected 34 companies have a great regressive power of higher than $50 \%$ in the stock prices. This indicates that macroeconomic variables have a higher power in predicting the stock prices. In regression, null hypothesis results indicate that Ms, exchange rate, interest rate and inflation rate of the companies collectively do not deal with any impact on stock market prices. A higher $\mathrm{R}^{2}$ of the regression results shows that the model was good and macroeconomic variables in explaining sock prices have a higher explanatory power. They found that inflation rate and exchange rate were in opposite to CSE, means that they have a negative relationships. Whenever there was any increase in the interest rate, the investors then try to switch out of stocks, which directly affect the 
stock prices to fall. Lagged money supply was having no any strong predictive power of the fluctuation in stock market prices. At last, he said that these findings were more helpful for those who made policy, stock market regulators, investors and those who analyze the market for investment purposes.

Nishat and Shaheen (2004) used VECM (vector error correction model) model in their research. The main finding that they note were that, (i) by using the VECM model, five variables are co integrated and other two are in long term equilibrium relationships among the variables. This shows that IPI has the strong influence in determining the Pakistani stock prices and inflation has the strong negative determining effect in stock prices. (ii) Granger causality test indicated that a causal relationship is present in between the economy and equity market. It means that macroeconomic variables have a link to cause the movement in stock market prices. But in case of industrial production index and stock prices causal relationship, there was a reverse relationship.

Gay (2008) worked for the emerging economies like Brazil, India, Russia and china to find the same relationship. After all the tests and analysis, he concluded that there was no any major impact of exchange rate and oil prices on the stock market prices on any of the chosen countries. The reason may be the pressure of domestic and international macroeconomic factors on stock market returns. Further, they note that by analyzing the data, there were no any large relationships in the current and previous stock market returns. This means that these countries i-e Brazil, Russia, India and china were running the weak and in-efficient equity market.

Hassan and Nasir (2008) tried to find out that how the macroeconomic variables cause fluctuation and volatility in the capital market. The conclusion which they had drawn were, that by using the ARDL approach method, the following characteristics were being observed as, no econometric problems, no model specification errors, non-stationary property due to logarithmic transformations, heteroscdasticity were observed neutral, etc.

In the long-run relationship, IPI, oil prices, CPI, were insignificantly determining the equity prices while, interest rate, exchange rate, and money supply were positively playing the effective role in finding the equity prices. Similarly, in short-run relationship results, IPI, oil prices, CPI were not effective while interest rate, exchange rate and money supply were effective in determining the equity prices. On the other hand, foreign portfolio investment proves to be significant in short run while non effective in long run. 
Their findings clearly show that exchange rate, money supply and interest rate are best in predicting the direction of equity prices in capital market. So investor must have to look at these variables while investing in the stock market. Also the government must have design the macroeconomic policies in a wise way, to efficiently run the capital market. Monetary policies regulate the supply of money and indirectly the interest rate. So, state bank must have to regulate it in a careful way.

Mohammad, Hussain, Jalil, and Ali (2009) conduct their research to find the correlation among their variables which they had selected. Like other researches, this research has also shown a significant effect of macroeconomic variables on stock market prices. Data which were being observed was not constantly changing. So there was much irregularity in the data. From the result, they concluded that exchange rate and foreign exchange reserves have affected the stock prices significantly. Similarly, interest rate and broad money supply M2 which are strongly correlated have negatively affected the stock prices. Only the few variables like industrial production index and gross fixed capital formation have a negligible effect on stock prices. This bring us into a conclusion that during this time period, capital formation made by firms and industrial production have not affect the stock prices.

Buyuksalvarci (2010) similarly conducted the research on Istanbul stock exchange. His whole research was under the framework of arbitrage pricing theory (APT). Based on his view, he collects data and run the regression. From the result, he found that some factors have the negative effect on stock returns like interest rate, foreign exchange market rate, industrial production index, and oil prices. While broad money supply which is the major component of economy have positively affected the stock returns. The reason is that, changes in money supply automatically bring changes in the money market and real economic variables. On the other hand, CPI and gold prices were having negligible effect on ISE-100 index returns.

\section{Data Analysis}

\subsection{Data}

The main objective of this research is to examine the impact of macroeconomic variables on stock exchange market. Variables like KSE-100 index, CPI, exchange rate, foreign portfolio liabilities( equities), oil prices and t-bill rates has been selected in the research. Quarterly data has been collected from the period of 1992 to 2009 for the above variables. Most of the data has been taken from IMF database and econstat.com website. 


\subsection{ADF test}

Augmented dickey fuller test is used to testify and examine the stationarity in the data. Time series data has the quality of non stationarity which need to be making stationary before running any regression or models. It means that data is collected through uniform intervals and has a unit root problem. If the data is regressed then the series will slip back to the mean value. Thus it is necessary to run the ADF test on each variable. ADF test removes the non stationary property from the data.

The hypothesis that I have drawn for ADF test are;

i. T-statistics $>$ ADF critical value $\rightarrow$ Ho: $\delta=0$ (unit root) not reject the null hypothesis. It means that series has unit root problem.

ii. T-statistics $<$ ADF critical value $\rightarrow \mathrm{H} 1: \delta \neq 0$. Reject the null hypothesis. It means that series has no unit root problem.

Negative value in the outcome of an ADF test result has a great importance. It means that if any variable shows greater negative value, it will be the possibility to reject the null hypothesis and the data will be moving towards stationarity. Before moving towards the model in a research work, I tested the variables for stationarity on ADF test with Schwarz information criterion for lag length adjustment and non-stationarity removing.

\subsection{Model}

To find the long run relationship between the variables, I have select ARDL (auto regressive distributed lag model) approach model.The model has been named because of showing lag differences in both dependent and independent variables. For finding the relationship between the time series variables data, many researchers have used different methods like, Engle and Granger (1987) test, OLS method used by Philips and Hensen's (1990), maximum likelihood method by Johansen-Juselius tests (1990). These methods were used in old stages and certain faults have been recognized like these methods require the variables which were in the order of one i.e. I (1). Also these methods require lower power of variables to find estimation results. By looking at this, modern researchers have developed a new approach which is ARDL model. The most famous work done on this approach has been done by Pesaran and Shin (1995), Perasan et al (2001). ARDL approach model has got advantage over the other model in a sense that, ARDL model can place a number of variables in comparison to other models i.e. VAR model. Secondly, the model can be applied without looking at the stationarity level in the data. 
The model which will be used to find the relationship between the macroeconomic factors and equity market is written below.

KSE-100 $=\beta 0+\beta 1$ Oil $t+\beta 2$ X-Rate $t+\beta 3$ T-bill $t+\beta 4$ CPI $t+\beta 5$ FPI $t$ Where

Oil = Oil prices in $\$$

X-rate $=$ Foreign Exchange Rates... Rs. $/ \$$

T-bill $=$ Six Month Treasury Bill Rate

$\mathrm{CPI}=$ Consumer Price Index

FPL $=$ Foreign Portfolio Investment liabilities (equities)

According to ARDL approach, above model can be represent as,

$$
\begin{gathered}
R t=\beta 0+S \text { i It }-1+S \text { i Oil } t-i+S \text { d iX-Rate } t-i+S \text { f iT-Bill t-i }+ \text { S I CPI } \\
t-i+S \text { i FPL } t-i+\mu t
\end{gathered}
$$

In the above model, $\mathbf{i}$ may take any value ranges from 1 to $\mathrm{p}$.

\section{Findings and Discussions}

ADF test result in table 1 clearly shows that most of the variables like CPI, exchange rate, oil prices, foreign portfolio liabilities (equities) were made stationary at the $2^{\text {nd }}$ difference with trend and intercept. It means that they were non stationary at level and at first difference order. However t-bill rates were showing stationarity at first difference level. The most non-stationary variable that has been observed was oil prices. Approximately 59 observations have been left after adjustment. The data in table 1 clearly shows the stationary property in the data. Their lower t-statistics value than critical values and negative coefficient values shows that there is now no unit root problem and we can reject the null hypothesis.

According to the table 2, result of ARDL model has revealed that all the data are statistically significant. All the macroeconomic variables have their own impact on dependent variable. The data has been stationary verified. $\mathrm{R}^{2}$ which shows the goodness of the model has been recorded as 0.95. It means that $95 \%$ of the variation in stock prices has been explained by the variation in independent variables. 
Table 1:

\begin{tabular}{|l|c|c|c|c|}
\hline Variable & Coefficient & Std. error & t-statistic & Prob. \\
\hline D(DCPI(-1),2) & -1.541130 & 0.149989 & -10.27496 & 0.0000 \\
D(DCPI(-1),3) & 0.695201 & 0.124295 & 5.593167 & 0.0000 \\
\hline D(X-Rate(-1),2) & -1.487801 & 0.168042 & -8.853743 & 0.0000 \\
D(X-Rate(-1),3) & 0.385947 & 0.114918 & 3.358445 & 0.0013 \\
\hline D(FPL(-1)) & -1.536137 & 0.101629 & -15.11516 & 0.0000 \\
D(FPL(-1),2) & -1.750275 & 0.080506 & -21.74081 & 0.0000 \\
\hline D(Oil(-1),2) & -11.84518 & 2.323335 & -5.098352 & 0.0000 \\
\hline D(T-Bill(-1)) & -0.590048 & 0.110618 & -5.334094 & 0.0000 \\
D(T-Bill(-1),2) & -1.882797 & 0.244042 & -7.715040 & 0.0000 \\
\hline
\end{tabular}

Table 2:

\begin{tabular}{|l|c|c|c|c|}
\hline Variable & Coefficient & Std. error & t-statistic & Prob. \\
\hline C & 454.7624 & 804.6683 & 0.565155 & 0.5740 \\
\hline CPI(-1) & -689.8723 & 135.9856 & -5.073128 & 0.0000 \\
CPI(-2) & 814.2750 & 141.1624 & 5.768358 & 0.0000 \\
\hline X-Rate(-1) & -482.4557 & 93.04892 & -5.184968 & 0.0000 \\
X-Rate(-2) & 303.9944 & 98.09061 & 3.099118 & 0.0029 \\
\hline FPL(-1) & 1.786583 & 0.579155 & 3.084809 & 0.0031 \\
FPL(-2) & 2.071081 & 0.602364 & 3.438255 & 0.0011 \\
\hline Oil(-1) & 139.0658 & 12.32215 & 11.28584 & 0.0000 \\
\hline T-Bill(-2) & -104.6203 & 40.78378 & -2.565243 & 0.0128 \\
\hline R-squared & 0.9515 & Akaike info criterion 16.666 & \\
Durbin-Watson stat & 1.147 & Schwarz criterion & 16.955 & \\
\hline
\end{tabular}

Substituted Coefficients:

$\mathrm{KSE}=454.76-689.87^{*} \mathrm{CPI}(-1)+814.28 * \mathrm{CPI}(-2)-482.45^{*} \mathrm{X}$-Rate $(-1)+303.99 * \mathrm{X}-$ Rate $(-2)+1.79 *$ FPL $(-1)+2.071 *$ FPL $(-2)+139.06 *$ Oil $(-1)-104.62 * \mathrm{~T}-$ Bill $(-2)$

\section{Conclusions}

This research work provides a broader area to find the impact of macroeconomic variables on stock market. Much research work has been done be- 
fore in different countries with different statistical tools and with theoretical framework. The whole research work data has been collected from the period of 1992 to 2009 on quarterly basis. KSE-100 index data has been used as proxy for stock market performance. Because this index shows the top 100 highly capitalized companies share performance. In macroeconomic variables, five major variables of an economy has been selected which are CPI, foreign exchange rate, foreign portfolio liabilities(equities), oil prices and t-bill rates. During this time much fluctuation has been observed in CPI and in oil prices. Data were non-stationary at level and at first difference of an ADF test. ADF test were made to bring the data in stationary mode.

Results of the ARDL model provide evidence that CPI, exchange rate, and t-bill rate has been negatively related with KSE-100 index. While foreign portfolio liabilities (equities) and oil prices have positively and with minor related with stock market prices. During this time period, Pakistani rupee has been devalued with the passage of time. So our share prices and exports were getting cheaper for the foreigners. This phenomenon attracted the foreign investors to invest in Pakistan stock market at first, but in the last years, due to security problem their confidences in investing in Pakistan were losing gradually. A foreign portfolio liability has minor effect on stock prices and exchange rate showed the negative effect on stock prices.

\section{References}

1. Mansoor ibrahim, H. A. (1998). Macroeconomic variables and the Malaysian equity market. Kulliyyah of economics and management sciences. Kuala Lampur international Islamic University of Malaysia: 22.

2. Menik (2002). Effect of macroeconomic variables on stock prices in emerging Sri Lankan stock market. Accountancy and finance. Belihuloya, sabaragamuwa: 18.

3. Muhammad Nishat, R. S. (2004). Macroeconomic factors and equity market. Finance and economics. Karachi, IBA.

4. Arshad Hassan, Z. M. N. (2008). "Macroeconomic factors and equity prices: empirical investigation by using ARDL approach." the Pakistan development review 47(4): 501513.

5. Gay, R. D. (2008). "Effect of macroeconomic variables on stock market returns for four emerging economies: Brazil, Russia, India and China.” international business and economics research $7(3)$.

6. S.D. Mohammad, A. H., Anwar Jalil, Adnan Ali (2009). "Impact of macroeconomic variables on stock prices." European journal of scientific research 38(1): 8 . 
7. Buyuksalvarci, A. (2010). "Effect of macroeconomic variables on stock returns: evidence from turkey." European journal of scientific research 14: 3. Pp. 404-416.

8. (2011). Impact of Foreign Reserves on Karachi Stock Exchange Market of Pakistan.

9. Shah, M. A. (2008). How the Karachi Stock Exchange (KSE) can be improved. School of Management, Blekinge Institute of Technology, Sweden, blekinge institute of technology. Master: 60.

10. Mohammad El Hedi AROURI, A. L., Makram Bellalah (2010). "Oil price shocks and stock market returns in oil exporting countries: the case of GCC countries.” international journal of economics and finance 2(5): 8 .

11. Sofia B. Ramos, H. V. (2009). Asymmetric effects of oil price fluctuations in international stock markets: 27.

12. Imarhiagbe, S. (2010). "Impact of oil prices on stock markets: empirical evidence from selected major oil producing and consuming countries." Global journal of finance and banking issues $4(4)$.

13. Al-Fayoumi, N. A. (2009). "Oil prices and stock market returns in oil importing countries: the case of Turkey, Tunisia and Jordan." European journal of economics, finance and administrative sciences (16).

14. Nooreen Mujahid, R. A., Khalid Mustafa (2005). Does oil price transmit to emerging stock returns: a case study of Pakistan Economy, University of Karachi.

15. Muhammad Ishfaq Ahmad, R. U. R., Awais Raoof (2010). "Do interest rate, exchange rate effect stock returns? A Pakistani perspective." international research journal of finance and economics (50).

16. Oguzhan Aydemir, E. D. (2009). "The relationship between stock prices and exchange rates evidence from turkey." International research journal of finance and economics (23).

17. Charles Adjasi, S. K. H., Daniel Agyapong (2008). "Effect of exchange rate volatility on the Ghana stock exchange" African journal of accounting, economics, finance and banking research 3(3).

18. Trevino, R. C. and B. M. Yates "treasury bills and inflation." Journal of financial planning.

19. Amadi, C. A. (2008). Impact of risk free rate on stock returns evident from Karachi stock exchange Pakistan. 
20. Zafar, N., S. F. Urooj, et al. (2008). Interest rate volatility and stock return and volatility. European journal of economics, finance and administrative sciences. Islamabad, Mohammad Ali Jinnah University.

21. Yuan, L. and L. Chen (2010). "The relationship of stock returns and inflation in China." international conference on E-Business and E-Government: 5319-5322.

22. (2011). Pakistan December CPI seen up 16 per cent. Karachi, Dawn newspaper.

23. Zaidi, E. (2011). Inflow of FPI in Pakistan. The Nation. Karachi: 1.

24. Hasan, A. Javed, et al. (2008). "Macroeconomic influences and equity market returns: a study of an emerging equity market." Journal of economics and economic education research $10(2)$.

25. Poshakwale, S. and C. Thapa (2007). Impact of foreign portfolio investments on market co-movements: evidence from the emerging Indian stock market. International equity markets co-movements and contagion. Cass business school, London: 27.

26. Rogalski, R. J. and J. D. Vinso (1974). Stock returns, money supply and the direction of causality. Rodney L. white center for financial research. Philadelphia, university of Pennsylvania: 28 .

27. Oskooe, S. A. P. (2010). "Emerging stock market performance and economic growth." American journal of applied sciences 7(2): 265-269.

28. Hussain, S. (2010). Impact of foreign reserves on Karachi stock exchange market of Pakistan, Articlebase.com.

29. Tunah, H. (2010). "The analysis of relationships between macroeconomic factors and stock returns: evidence from turkey using VAR model.” international research journal of finance and economics(57).

30. Maghayeresh, A. (2003). "Causal relations among stock prices and macroeconomic variables in the small, open economy of Jordan." European journal of economics, finance and administrative sciences $17(2)$ : 3-12. 